Prepared for the U.S. Department of Energy

under Contract DE-AC05-76RL01830

\title{
Building Energy Efficiency in India: Compliance Evaluation of Energy Conservation Building Code
}

S Yu

M Evans

A Delgado

March 2014

\section{Pacific Northwest}

NATIONAL LABORATORY

Proudly Operated by Battelle Since 1965 



\section{DISCLAIMER}

This report was prepared as an account of work sponsored by an agency of the United States Government. Neither the United States Government nor any agency thereof, nor Battelle Memorial Institute, nor any of their employees, makes any warranty, express or implied, or assumes any legal liability or responsibility for the accuracy, completeness, or usefulness of any information, apparatus, product, or process disclosed, or represents that its use would not infringe privately owned rights. Reference herein to any specific commercial product, process, or service by trade name, trademark, manufacturer, or otherwise does not necessarily constitute or imply its endorsement, recommendation, or favoring by the United States Government or any agency thereof, or Battelle Memorial Institute. The views and opinions of authors expressed herein do not necessarily state or reflect those of the United States Government or any agency thereof.

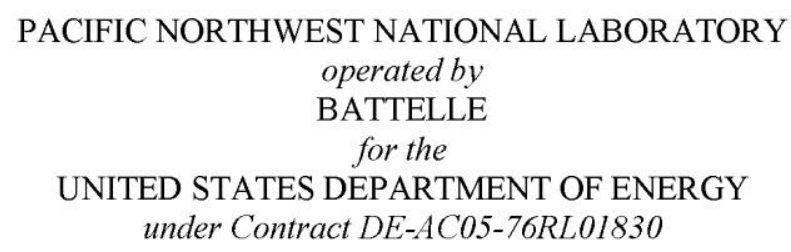

Printed in the United States of America

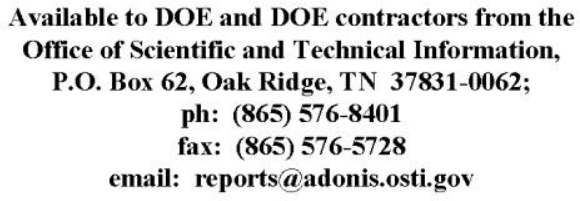





\title{
Building Energy Efficiency in India: Compliance Evaluation of Energy Conservation Building Code
}

\author{
Sha Yu, Meredydd Evans, Alison Delgado \\ Pacific Northwest National Laboratory
}

\section{Introduction}

India is experiencing an unprecedented construction boom. The country doubled its floorspace between 2001 and 2005 and is expected to add 35 billion $\mathrm{m}^{2}$ of new buildings by 2050 (Shnapp and Laustsen, 2013). Buildings account for 35\% of total final energy consumption in India today, and building energy use is growing at $8 \%$ annually (Rawal et al., 2012). Studies have shown that carbon policies will have little effect on reducing building energy demand (Chaturvedi et al., 2014; Yu et al., 2014). Chaturvedi et al. (2014) predicted that, if there are no specific sectoral policies to curb building energy use, final energy demand of the Indian building sector will grow over five times by the end of this century, driven by rapid income and population growth. The growing energy demand in buildings is accompanied by a transition from traditional biomass to commercial fuels, particularly an increase in electricity use. This also leads to a rapid increase in carbon emissions and aggravates power shortages in India. Growth in building energy use poses a challenge for the Indian government.

To curb energy consumption in buildings, the Indian government issued the Energy Conservation Building Code (ECBC) in 2007, which applies to commercial buildings with a connected load of $100 \mathrm{~kW}$ or $120 \mathrm{kVA}$. Previous studies estimated that the implementation of ECBC could help save 25-40\% of energy, compared to reference buildings without such energyefficiency measures (IEEMA, 2007; Tulsyan et al., 2013). However, the impact of ECBC depends on the effectiveness of its enforcement and compliance. Currently, the majority of buildings in India are not ECBC-compliant. The United Nations Development Programme projected that code compliance in India would reach 35\% by 2015 and 64\% by 2017 (UNDP, 2011). Whether the projected targets can be achieved depends on how the code enforcement system is designed and implemented. 
Although the development of ECBC lies in the hands of the national government - the Bureau of Energy Efficiency under the Ministry of Power, the adoption and implementation of ECBC largely relies on state and local governments. Six years after ECBC's enactment, only two states and one territory out of 35 Indian states and union territories formally adopted ECBC and six additional states are in the legislative process of approving ECBC (BEE, 2013). There are several barriers that slow down the process. First, stakeholders, such as architects, developers, and state and local governments, lack awareness of building energy efficiency, and do not have enough capacity and resources to implement ECBC. Second, most jurisdictions have not yet established effective legal mechanisms for implementing ECBC; specifically, ECBC is not included in local building by-laws in most jurisdictions or incorporated into the building permitting process. Third, there is not a systematic approach to measuring and verifying compliance and energy savings, and thus the market does not have enough confidence in ECBC.

Previous studies and reports have addressed the first and second barriers. Kumar et al. (2010), Rawal et al. (2012), and Williams and Levine (2012) identified implementation strategies to improve capacity and remove institutional barriers. The study by Yu et al. (2012) and the Administrative Staff College of India and the Natural Resources Defense Council (2012) provided suggestions on motivating stakeholders and implementing ECBC at the state level. Yu et al. (2013) and the Shakti Foundation (2013) proposed using third-party inspectors to help states build capacity and roll out ECBC implementation rapidly. However, none of the previous studies provides solutions on how to evaluate ECBC compliance and associated energy savings. Compliance evaluation is critical. It helps build confidence in the private sector and facilitates deployment of energy efficiency technologies. In addition, compliance evaluation can help roll out implementation, as state and local governments can prioritize areas for enforcement and develop incentives and penalties based on evaluation results.

Energy codes achieve energy savings only when projects comply with codes, yet only a few countries measure compliance consistently. China and the U.S. appear to be two countries with well-developed evaluation systems, which over time, if applied consistently, will likely help raise compliance. The United States recently developed methodologies measuring compliance with building energy codes at the state level. China has an annual survey investigating code compliance rate at the design and construction stages in major cities. Like many developing 
countries, India has only recently begun implementing an energy code. International experience on code compliance may provide ideas on building strong compliance assessment into India's code system from the outset. In this paper, we examine lessons learned from the U.S. and China on compliance assessment and provide information on options for conducting compliance evaluation, which could help national, state, and local governments in India to improve compliance and speed up ECBC implementation.

\section{Importance of Code Compliance Evaluation}

Studies have shown that robust enforcement and high compliance rate is critical to achieving intended energy savings and that improvement in the stringency of energy codes does not matter when the compliance rate is low (Harper et al., 2012; Nordeen, 2013; Stellberg, 2013; Yu et al., 2014). Effective compliance and enforcement unlock deeper energy savings, reduce costs, increase building resale value, and minimize environmental impact.

This paper focuses on compliance evaluation, which refers to a set of processes and procedures through which factual information is provided, assessed, and checked to determine whether buildings effectively meet respective energy code requirements. Compliance evaluation can play a key role in building trust among stakeholders and instill confidence in the market to deploy and invest in energy-efficient building technologies. It is crucial to develop a common methodology for compliance evaluation for purposes of accountability and credibility of the codes program. Compliance evaluation can also help state and national governments track the progress of ECBC implementation.

Compliance evaluation is critical to designing effective policies, because it allows policy makers to make improvements to programs over time based on hard data. Comparison between Denmark and Sweden provides a sharp focus on the importance of evaluation in policy making. Denmark has robust evaluation of most of its energy efficiency programs and has made a concerted effort to learn from its evaluations in developing policy and long-term strategy. For example, on the issue of building energy codes, Denmark ${ }^{1}$ has adjusted its compliance procedures over time to improve compliance; as a result, energy consumption per unit of floorspace in all of its buildings

\footnotetext{
${ }^{1}$ Appendix A briefly describes the compliance system in Denmark.
} 
has declined greatly in recent years. Sweden, in contrast, has not conducted substantial evaluation, and its results in terms of building energy performance, while noteworthy, have not been as robust. New buildings in Sweden today may be less efficient than they were in the late 1980s, even though the requirements are more stringent today (DEA, 2012; Evans and Yu, 2013; GBPN, 2013; McCormick and Neij, 2009; SBi, 2008; SEA, 2012, 2013).

As India just started its energy code implementation, conducting compliance evaluation can help Indian policy makers to identify potential problems in ECBC implementation and make improvements accordingly. Compliance evaluation will also help India achieve its intended energy savings and emissions reductions through ECBC.

It is also important to note that compliance evaluation is different from regular compliance checks that are used to enforce energy codes. Compliance checks are part of the code enforcement procedures; code officials or third-party inspectors check and verify if a single building complies with the requirements of the codes at the design and construction stages and then issue building permits. In contrast, compliance evaluation assesses the overall compliance rate of all buildings and may involve using statistical methods instead of checking every single building. Compliance evaluation can identify major issues in code compliance based on large building stocks and survey results and help policy makers prioritize areas for improvements. Another difference is that compliance checks are usually conducted during the building's design and construction, and compliance evaluation is often used in a retrospective way to assess if buildings are code compliant (Figure 1). 


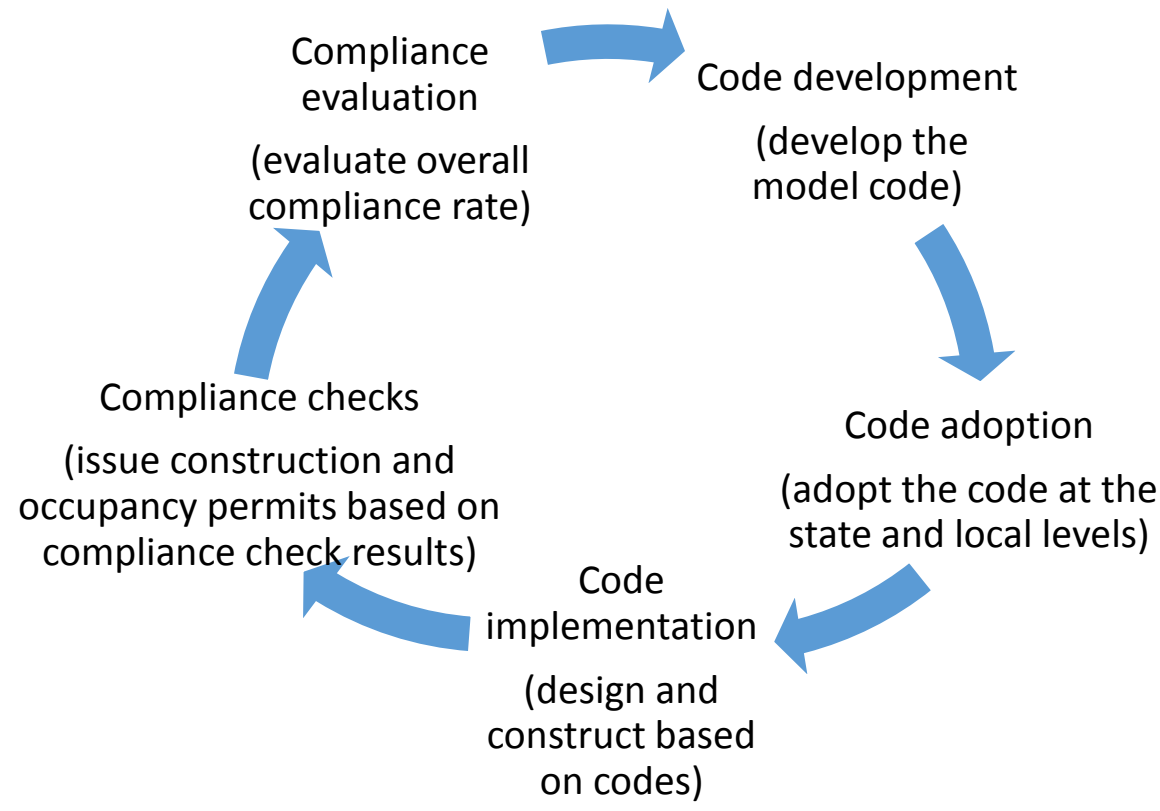

\section{Figure 1. The cycle of energy code development and implementation}

Although compliance checks and compliance evaluation are different, they share steps that determine if the building is code compliant. Box 1 lists the basic steps in compliance checks, and many of these steps are also used in compliance evaluation, including review of building plans and specifications; evaluation of products, materials and equipment specifications; review of tests, certification reports and product listings; review of supporting calculations. In addition to using evaluators to inspect buildings based energy code requirements, compliance evaluation also analyzes data collected from individual buildings and generates an overall compliance rate at the national or state levels.

Box 1. Basic compliance check steps in energy code enforcement

- Review of building plans and specifications

- Evaluation of products, materials and equipment specifications

- Review of supporting calculations

- Inspection of the building and its systems during construction

- Review of tests, certification reports and product listings for installed materials

- Evaluation of materials substituted in the field

- Inspection immediately prior to occupancy

Source: (DOE, 2013). 


\section{Energy Code Compliance Evaluation in the U.S.}

Like India, in the United States, adoption and enforcement of energy codes falls under the purview of states and localities. As building energy codes in the U.S. become more stringent, the U.S. building energy program started to focus on compliance and developed a plan to achieve $90 \%$ compliance with the model energy code by 2017 , which requires active training and enforcement programs as well as annual measurement of the rate of compliance. Many states, territories, and jurisdictions are creating plans and mechanisms to measure and improve compliance with their energy codes. To support these efforts, the U.S. Department of Energy ${ }^{2}$ developed a guide to help state and local jurisdictions to measure and report energy code compliance, supplemented by an online tool to generate statistically representative samples.

\section{$\underline{\text { Assessing compliance }}$}

Compliance evaluation proposed in the U.S. follows statistical methods, meaning only a sampling of buildings are assessed for the compliance evaluation. In addition, the U.S. approach does not calculate actual energy savings or energy use intensity of the buildings; it only checks if the building is constructed in accordance with building energy codes adopted by the state and local jurisdictions (PNNL, 2010).

DOE’s 2010 report "Measuring State Energy Code Compliance"”3 (Evaluation Methodology) provides specific guidelines to help states measure code compliance rates, and it divides compliance evaluation into four steps. First, the state needs to obtain the evaluation checklists ${ }^{4}$.for both residential and commercial buildings based on the version of the energy codes implemented in the state (Appendix B). Different code provisions are weighted based on their impacts on building energy consumption, namely high impact (Tier 1), medium impact

\footnotetext{
${ }^{2}$ The U.S. Department of Energy's role, defined by statutory requirements, supports energy efficiency in buildings by developing and implementing model codes and standards, and provides technical assistance to states and localities in their process to adopt and enforce energy codes.

${ }^{3}$ This report is available at https://www.energycodes.gov/sites/default/files/documents/MeasuringStateCompliance.pdf.

${ }^{4}$ Appendix B provides sample checklists for ASHRAE Standard 90.1, which ECBC is based on. For the complete checklists and instructions, please visit the U.S. Building Energy Codes Program https://www.energycodes.gov/compliance/evaluation/checklists.
} 
(Tier 2), and low impact (Tier 3). Second, the state needs to determine which buildings ${ }^{5}$ in the state to inspect. The U.S. Building Energy Codes Program provides an online tool to generate a statistically significant number of buildings to inspect for residential new construction, residential renovations, commercial new construction, and commercial renovations. Factors to consider in sampling include building type and size, location by county and climate zone, and other factors. Third, the state sends out evaluators to inspect buildings according to energy codes requirements and fill checklists. Finally, the state analyzes the collected data from individual buildings and generates an overall state compliance metric based on statistical methods. The compliance rate could be calculated for individual buildings, building groups, and at the county, state, and national levels. These breakdowns are important because knowledge of the associated compliance rates or gaps at large can improve policy design and implementation.

DOE's Evaluation Methodology underscores the importance of ensuring that a state strikes a balance across building use, ownership and design when sampling their buildings. Thus, representative building samples will include both energy-intensive building use types, such as hotels and other lodging, in addition to less-energy intensive buildings such as storage buildings. Likewise, a representative sample will include buildings with different ownership types to reduce the likelihood of bias in determining compliance. For example, in the United States, schools are more likely to be owned and operated by state and local government and are therefore more inclined to be in compliance with state and local codes, both because the owner has a vested interest in the ownership and operating costs, and because it is under greater public scrutiny (PNNL, 2010). Thus, a sample with more of these types of buildings could skew the results towards increased compliance.

\section{Steps to implement code compliance assessments}

Since the Evaluation Methodology was published in 2010, DOE has taken steps to make further improvements to the methodology and also provided supplemental resources to assist states in

\footnotetext{
${ }^{5}$ DOE recommends a sample size of 44 buildings. However, DOE also recognizes that this recommended sample size may be more or less for some populations in some states, depending on the degree of new commercial building construction in the state. For example, additional building samples may be required for very large commercial buildings (larger than 250,000 $\mathrm{ft}^{2}$ ). DOE also takes into account simple versus complex buildings. Because the complexity of a building is closely tied to building size, DOE recommends that states include in their samples commercial buildings that are distributed equally within three major building size strata (small: up to $25,000 \mathrm{ft}^{2}$ in conditioned floor area, medium: $25,000 \mathrm{ft}^{2}-60,000 \mathrm{ft}^{2}$, and large: $\left.60,000 \mathrm{ft}^{2}-250,000 \mathrm{ft}^{2}\right)$, unless a state has limited amount of new construction in any one of the building size stratum.
} 
raising compliance levels. In particular, DOE piloted the compliance methodology across several U.S. states, and the experiences of those pilot studies have led to a number of recommendations and potential changes to the DOE methodology. In particular, the pilot studies revealed that (EERE, 2013):

- Consistency is challenging to achieve across studies and among individual evaluators. For this reason, additional guidance and instructions on DOE compliance checklists, evaluator training and quality assurance of gathered data is essential.

- The checklists developed by DOE were valuable tools for local evaluators. State and local staff involved in code compliance during their normal course of code enforcement could also benefit from these checklists.

- Software tools (COMcheck and REScheck) based on trade-off and prescriptive-based compliance approaches demonstrated a strong correlation with higher compliance rates. Notably, documentation produced by software tools help to address prevalent barriers to compliance, such as lack of training, lack of resources and lack of compliance information on plan submissions.

- Data sources for generating sample sets are not always accurate and, in some cases, are not available. State compliance evaluation studies are also costly.

- Access to buildings under construction was a major problem in some locations. Early engagement of state and local governmental agencies is imperative to ensure their cooperation.

The pilot studies illustrate the fact that one size does not fit all. In all the cases that DOE evaluated, deviations from the DOE methodology related to cost and/or time considerations. As a result, DOE is developing additional procedures that can address alternative approaches with these common barriers in mind (EERE, 2013). Alternative approaches include: post-construction evaluation, evaluation of a subset of compliance requirements, second-party evaluation (i.e., evaluation conducted by local government officials), spot-check evaluation, and trade-off and performance compliance approaches. The pilot studies show the importance of offering flexible mechanisms that can be tailored to local conditions. At the same time, it is important to acknowledge the trade-offs associated with using alternative approaches that may reduce the statistical significance of the results of code compliance evaluations, and to account for these 
trade-offs when assessing code compliance at the national level. The studies also served to increase dialogue with local jurisdictions, educate and heighten awareness about energy codes to building departments, and helped identify and execute training needs.

DOE has also made improvements to its sample generator tool and compliance software tools to make the process of code compliance and evaluation more seamless (GPO, 2013). On August 2013, DOE also soliciting public input on the 2010 Evaluation Methodology to assist in assessing compliance with building energy codes at the local, state, and national levels (GPO, 2013).

Code compliance evaluation in the U.S. just started recently and there is not a reported national compliance rate. However, pilot studies have shown that compliance evaluation is critical to improving overall code enforcement (Harper et al., 2012; Nordeen, 2013), and the U.S. may achieve its $90 \%$ compliance goal by 2017 by rolling out full-scale compliance evaluation.

\section{Compliance Evaluation in China}

China is the world's largest market for new construction, adding 0.4 to 1.6 billion square meters of floor space annually (Evans et al., 2010). In response to this rapid growth, China has introduced several initiatives over the past few years to enhance energy efficiency in its buildings industry. The Chinese energy codes consist of three options for compliance: first, a prescriptive path which contains detailed specifications for individual components, second, an alternative to the prescriptive approach allowing trade-offs between envelope components, and third, a performance path that requires that the energy consumption of the design features of the proposed new building does not exceed energy consumption of a reference building. Chinese codes are mandatory at the national level, but local governments can adopt codes that are more stringent. In support of the national requirements, China has established a multi-step protocol for enforcement of their building codes, including energy codes. Often, third parties are intimately involved in the enforcement of building codes during the construction of a project (Evans et al., 2010). They perform the first level check to verify that the design and construction is aligned with the codes. A second level check is performed by quality control and testing stations that review the documents submitted by third parties and do some of their own checks. 


\section{$\underline{\text { Annual compliance assessment }}$}

Besides the checks included in each construction project, since 2005, the Chinese Ministry of Housing and Urban Development (MOHURD) has commissioned around ten survey teams every year to conduct an inspection of randomly selected medium and large buildings in urban areas in 31 provincial territories (Shui and Nadel, 2012). The inspection is mandatory for residential new construction over 50,000 square meters and for commercial new buildings with a total investment of over 30 million yuan $\left(\sim \$ 4.9\right.$ million $\left.^{6}\right)$. (Evans et al., 2010; MOHURD, 2011; Shui and Nadel, 2012). Compliance with building energy codes is one of the focal points of the annual inspection check. Unlike the compliance check in the U.S., the annual construction inspection in China also involves enforcement. If a building does not meet requirements of corresponding energy codes, it will receive notice to correct the problem within a certain period of time. This practice, to some extent, also leads to skewed results in compliance rates.

Cities that are selected for inspection are required to provide an inventory of the construction projects that have completed the drawing inspection stage. The inspectors, which include MOHURD officials, building energy code experts, or local code management and enforcement officials from alternate jurisdictions, verify whether relevant national and local building energy efficiency policies and regulations have been implemented. They also check whether compliance with mandatory items in design standards has been met.

The compliance evaluation of Chinese codes enforcement also involves sampling and checklists. Different from the U.S. approach that state and local jurisdictions evaluate compliance, the Chinese takes a top-down approach. MOHURD assembles 10 evaluation teams, and each team conducts compliance evaluation in two to three provinces ${ }^{7}$. Four large municipalities (i.e. Beijing, Shanghai, Tianjin, and Chongqing) and the capital city of each province are always included in the national compliance evaluation. The evaluation team also randomly selects ${ }^{8}$ one additional prefecture-level city and one additional county-level city in each province for compliance evaluation, and rural areas are not included in the evaluation. In each city, the evaluation team randomly picks several projects to assess project documentations or conduct onsite inspections. However, the number of projects evaluated is quite small. For example, in 2011,

\footnotetext{
${ }^{6} 1$ Chinese Yuan $=0.16$ US dollar.

${ }^{7}$ There are 31 provinces and territories in China.

${ }^{8}$ There is no public documentation explaining how the cities are randomly selected.
} 
the inspection team only selected 12 buildings for compliance evaluation (six for design evaluation and six for construction inspection) in a prefecture-level city, and only six buildings were selected in a county-level city. Checklists used in compliance evaluation in China are also developed based on requirements in energy codes. However, the Chinese checklists weigh each item equally and do not differentiate requirements based on their impacts on building energy use.

\section{Acceptance code}

In addition to the energy codes themselves, inspectors refer heavily on China's Code for Acceptance of Energy Efficient Building Construction to verify compliance. Introduced in 2007, the 70-page long Code for Acceptance attempts to raise the bar in code enforcement by making compliance with building energy efficient requirements mandatory for the final approval of a construction project (Evans et al., 2010; Shui and Nadel, 2012). The Code for Acceptance addresses construction quality, testing and documentation for the building envelope, HVAC systems, lighting, monitoring and controls. For every building component included in the Code for Acceptance, there is a list of specifications that the item must meet and a description of the inspection method (Evans et al., 2010). The guidelines in the Acceptance Code make compliance of certain design elements an integral step in a construction project that may have otherwise proceeded unchecked. For example, manufacturers seldom provide the results of thermal resistance tests for their products, but the Acceptance Code requires the construction supervisor to test samples of the material, many times sending them to a test lab. Since the Code of Acceptance was adopted, China has experienced improved compliance rates in large urban areas (IEA, 2013), demonstrating the value in its coordinated and multi-layered enforcement system.

\section{$\underline{\text { Results and areas for improvement }}$}

In terms of information disclosure, MOHURD releases the nation-wide compliance rate on its website and lists provinces with good performance. The compliance rate during the 2011 inspection for the design stage is $100 \%$ and for the construction stage is $95.5 \%$. However, the compliance rate is not representative at the national level for several reasons. First, China's compliance assessment system has been tested only on a relatively small scale, making it difficult to estimate a national compliance rate with high confidence. Only about $9 \%$ of China's total prefecture-level cities and 7\% of total county-level cities are inspected (Shui and Nadel, 2012). Second, cities in the survey are not randomly selected and more evaluations are conducted 
in large cities and metropolitan areas. Third, only a small portion of buildings is inspected in the selected cities and the relatively small sample size is not representative of the general population. Fourth, as the compliance rate is estimated based on medium and large projects in urban areas, it does not represent the compliance status in suburban and rural areas or in small buildings. Finally, MOHURD lacks a well-documented and transparent methodology for compliance evaluation ${ }^{9}$, and this leads to inconsistency in data collection and evaluation (Evans et al., 2010; Price et al., 2011; Shui, 2012; Shui and Nadel, 2012). Inconsistencies in data collection have also been reported; reasons for this may be the lack of solid material testing system and incomplete protocols for building simulation (Evans et al., 2010; Shui and Nadel, 2012).

Although the Chinese system is not perfect and does not represent all buildings, along with the acceptance code, it did help improve compliance and energy performance of Chinese buildings, at least in urban areas. For medium and large buildings in urban areas, the compliance rate for the design stage doubled in the past six years and the compliance rate at the construction stage also improved significantly. Compared to the U.S., China has a shorter history and less experience in energy codes development and implementation, but much more building construction. It is more effective for China, as well as other developing countries, to establish a functioning compliance evaluation system in major cities at the early stage of code implementation than waiting for years to develop a full-fledged compliance evaluation system.

\section{Lessons Learned on Compliance Evaluation}

Compliance evaluation is essential to helping countries achieve better compliance rates and informing policy makers about progress in code implementation. Besides the U.S. and Chinese approaches, there are multiple ways to conduct compliance evaluation and states and countries can design the program based on their own needs.

Surveys of energy performance of individual or groups of buildings. Even if compliance is not directly measured, baseline efficiency evaluations may be used to estimate compliance rates. Studies of energy efficiency programs often provide information on code compliance. For

\footnotetext{
${ }^{9}$ Since there is not an official MOHURD document we can refer to, most information presented in this paper was obtained from personal communications and previous studies.
} 
example, the State of Arkansas conducted an energy survey in 100 new homes to determine energy performance of current building practices. With a focus on assessing energy consumption of homes, the survey included a blower door test and a heating and cooling load analysis, which helps builders and prospective buyers compare estimated utility costs with the costs associated with meeting the energy code. The information collected in this survey would also help the State Energy Office improve both code compliance and energy performance. Similar studies have been conducted in other states to determine energy savings as well as code compliance through on-site inspections. (Brown, 1999; Misuriello et al., 2010; Xenergy, 2003).

Assessments of energy savings in simulated buildings. Studies have compared model predictions, based on the design alone, with building designs and prototypes to decide if the building meets the energy standards. Many European countries take this approach to estimating energy savings and impacts of building energy standards. However, affected by behaviors and operations, actual energy use is likely to differ from model predictions. The Swedish study shows that the difference could be up to $250 \%$ (Karlsson-Hjorth, 2013). To improve the results, a few jurisdictions in Sweden and France have done small evaluations that compare actual energy use to the rated energy use that the building should attain based on its code compliance documents. Australia links it to periodic energy audits after the construction is completed.

Surveys of developers, architects, inspectors, or builders. When funding is limited for more complete evaluation, or in earlier implementation stages, states or countries can use simple surveys to assess the number of compliant buildings or how the compliant process went. In other cases, these surveys are used to supplement information obtained from plan reviews and field inspections to conduct in-depth analysis to identify major problems in code implementation.

These approaches, compared to methods used in the U.S. and China, are less expensive and resource-intensive, but there are also problems associated with these simple approaches. One major issue is that the small sample size used in these surveys and assessments is not representative and the results are often not statistically robust to generalize to all buildings. Although random sampling from all buildings in a jurisdiction is the ideal way to assess compliance rate, many jurisdictions often lack resources and capacity to conduct the analysis in this way, especially when on-site inspections are required. To make it feasible, most existing studies use stratified sampling and focus on areas of highest building activity and large buildings 
with greater impacts on energy use and emissions (Misuriello et al., 2010). Another problem is that some studies take a simple approach that only reviews building designs. However, there might be inconsistency between building plans and actual constructions, as indicated by Epstein et al. (2005) and Khawaja et al. (2007), and the modeled energy use based on designs are likely to differ from the actual energy consumption. Third, since these studies are conducted by local jurisdictions and use different methodologies, it is difficult to make a reasonable comparison across jurisdictions on their code enforcement efforts. It is also important to note that the result of compliance evaluation - compliance rate - varies by methodologies used, and compliance rate should be interpreted based on their methodologies.

Given these limitations, the U.S. and China aim to develop comprehensive methods for compliance evaluation, based on some key components that are essential to evaluating code compliance.

1. A statistical approach ${ }^{10}$ to evaluating and estimating compliance rates. Developing a robust and statistically sound method is important for compliance evaluation. In addition, to better use results for analysis, the methodology and results need to be released in a transparent manner.

2. Detailed compliance checklists for evaluators and code officials to measure and decide on whether the building complies with codes. In addition, compliance checklists could identify and highlight areas that are particularly problematic, which help policy makers to allocate resources in future policy development and implementation (Appendix B).

3. Priorities in compliance evaluation. The U.S. classifies codes requirements by their impacts, and prioritizes areas for evaluation and improvement based on impacts on energy consumption. China is developing its codes system and lacks capacity to enforce energy codes at a large scale, and therefore, the initial compliance evaluation focuses on major cities.

4. A consistent methodology. The studies in both the U.S. and China found that consistency is challenging to achieve across studies and individual evaluators. A solid

\footnotetext{
${ }^{10}$ The Chinese program was not originally designed to be statistical. Although the current Chinese results are still not statically representatives, as the program evolves, MOHURD starts to enlarge sample size and pay attention on statistical robustness.
} 
methodology, transparent reporting system, clear guidance and instructions on compliance checklists, and training of inspectors can help achieve consistent results.

5. Robust compliance software. Software tools (i.e. COMcheck and REScheck in the U.S. and PKPM-Energy in China) contributed to higher compliance rates. Documentation produced by software tools provides compliance information to code officials and inspectors upon plan submissions. It also helps address prevalent barriers to compliance such as lack of training and lack of resources.

However, neither country directly measures energy or $\mathrm{CO}_{2}$ savings from energy code implementation. Reductions in energy use and emissions are the ultimate goal for the development and implementation of energy codes. However, it is more difficult and costly to measure building energy use than to assess the compliance rate. Although neither country measures and verifies actual energy savings at present, they may add this component as the system of compliance evaluation gets mature. The City of Tokyo started to measure actual energy consumption and emissions from buildings since 2010, as it started the cap-and-trade program (Yu and Evans, 2013). Experience in Tokyo may help India and other countries evolve towards an outcome-based system (Appendix C).

\section{Policy Recommendations on ECBC Compliance Assessment}

Developing a compliance evaluation system would help the Indian government show the benefits of ECBC and build momentum for future implementation. Based on evaluation results, the Indian government can develop policies to target particular problems and improve ECBC implementation. Compliance evaluation also encourages the private sector to actively participate in energy code implementation.

As discussed above, compliance evaluation can be conducted by state/local jurisdictions or the national government. However, in either case, to ensure consistency in results, the methodology should be developed at the national level. The Bureau of Energy Efficiency (BEE) could develop a system and methodology for compliance evaluation.

The evaluation methodology needs to define statistical methods for sampling and estimation, such as how to select representative buildings based on building type and size, location, 
ownership, and climate condition. For example, the compliance evaluation needs to assess enough samples in both energy-intensive buildings such as hospitals and hotels and less energyintensive buildings like office buildings. Sampling also needs to consider the size of buildings, as compliance status of large and small building might be different. In addition, building ownership, whether it is a government facility or private commercial buildings, are also likely to affect their compliance behaviors.

To have a robust evaluation system, ECBC compliance checklists are also needed. Since ECBC is developed based on the ASHRAE Standard 90.1, ECBC compliance checklists could be developed based on the U.S. checklists (Appendix B). ECBC checklists could also weigh requirements based on their impacts, and there are some studies of Indian buildings that can help identify high-impact requirements and provisions (Manu et al., 2011; Rawal et al., 2012). Moreover, compliance checklists and other supporting materials can also benefit ECBC enforcement.

The list below summarizes the categories that can be included in ECBC compliance checklists ${ }^{11}$ :

- General information of the building: basic information of the building (name, address, floor area, state/city/jurisdiction, climate zone, building type (e.g. office, school, hotel, hospital, etc.), building ownership (e.g. state-owned, local government-owned, national account, or private), inspection date, and the responsible evaluator;

- Project type: new building, addition, or renovation;

- Selected compliance approach: prescriptive, trade-off, or performance;

- Code version: ECBC (if so, whether compliance software is used) or above-code program (e.g. Leadership in Energy \& Environmental Design);

- Compliance status: compliant, not compliant, not observable, or not applicable;

- Plans review verification: record of values and parameters found during plan review;

- Field verification: fillings of observed values based on field inspection, checks against values provided during plan review, and determination of compliance.

The state can tailor the standard evaluation methodology to its needs. The state or local governments may amend ECBC or develop localized interpretations of ECBC that might result

\footnotetext{
${ }^{11}$ This list is developed based on the compliance checklist of the U.S. Building Energy Codes Program.
} 
in modifications to ECBC requirements. Therefore, compliance checklists need to be climate zone specific or state specific. Moreover, most states only have limited capacity to enforce ECBC and can start from high-impact provisions and expand to full-scale ECBC implementation later.

Since Rajasthan is the first state to adopt ECBC, there are a few ECBC-compliant buildings in the state. Rajasthan can lead the effort in assessing the compliance rate, such as developing compliance checklists and evaluation methodology. Having compliance assessment can help the state to identify priority areas for improvement. For example, if most ECBC-compliant buildings are private commercial buildings in Rajasthan, the state can then provide incentives for public buildings to comply with ECBC or strengthen ECBC enforcement in the public sector.

Compliance evaluation requires coordination between state and local governments, as urban local bodies may collect compliance data while the state government analyzes data. Moreover, the state can list and compare compliance results among local jurisdictions and generate peer pressure for local jurisdictions to improve their performance. Municipalities with good compliance rates could also be rewarded. Compliance evaluation at the state level also requires coordination with BEE, as it shows in case studies that consistency in methodology is important to produce comparable results.

Compliance evaluation at the national level can be rolled out and implemented in the following steps. The initial stage of compliance evaluation can target methodology development and compliance evaluation in pilot regions and states. Then, national and state governments need to provide training and build capacity on compliance evaluation. Since the majority of trainings for evaluators overlap with conventional codes training, adding compliance evaluation into code implementation roadmap will not bring too much burden to the system. After the success in pilot states, compliance evaluation can be rolled out at the national level. There could be incentives to encourage state to conduct compliance evaluation. For example, the state's compliance rate could be used as one criterion to select states that receive the grant and assistance from BEE and other organizations. Finally, since ECBC is linked with the Energy Conservation Act, which sets targets for energy use intensity, beyond simple compliance evaluation, BEE could also develop a system to measure and verify actual energy and emissions savings induced by ECBC. 


\section{Conclusions}

Building energy codes are one of the most cost-effective tools to achieve energy efficiency in buildings. The key to realizing their full benefits is strong enforcement and compliance. Studies have shown that robust enforcement and a high compliance rate are critical to improving the energy performance of buildings and unlocking deeper energy savings. Both the U.S. and China have comprehensive compliance evaluation programs, and some key components of these programs include robust and consistent methods for compliance evaluation, applicable checklists of code requirements, and balances between deep energy savings and comprehensive coverage of building stocks. India can use these lessons learned from other countries to develop its own compliance evaluation approach. This requires the development of robust methodologies and technical support documents at the national level, as well as support and implementation at the state and local levels. Moreover, India has an opportunity to move beyond the existing efforts in the U.S. and China and measure actual energy savings and avoided $\mathrm{CO}_{2}$ emissions through ECBC implementation. How to measure actual energy savings in buildings is not discussed in this paper and can be studied in the future work; cases such as the Tokyo Cap-and-Trade program (Appendix C) sheds light on the potential design of the system.

Experiences from the U.S., China, and India in measuring compliance rate will help design a robust system elsewhere to ensure effective implementation of building energy codes, which in turn leads to reduction in building energy use and associated emissions. 


\section{References}

Administrative Staff College of India and Natural Resources Defense Council (ASCI and NRDC). 2012. Constructing Change: Accelerating Energy Efficiency in India's Buildings Market. Available at http://www.indiaenvironmentportal.org.in/files/file/Constructing\%20Change.pdf (accessed November 10, 2013).

Brown, E. 1999. Energy Performance Evaluation of New Homes in Arkansas. Available at: http://energycodesocean.org/sites/default/files/resources/arkansas.pdf.

Bureau of Energy Efficiency (BEE). 2013. "The Statewise Status of Activities for the Implementation of ECBC”. Bureau of Energy Efficiency. Available at http://www.beeindia.in/schemes/schemes.php?id=3 (accessed December 1, 2013).

Chaturvedi, V., Eom, J., Clarke, L.E., and Shukla, P.R. 2014. Long term building energy demand for India: Disaggregating end use energy services in an integrated assessment modeling framework. Energy Policy, 64, 226-242.

Danish Energy Agency (DEA). 2012. "Energy Efficiency Policies and Measures in Denmark.” ODYSSEE-MURE, Denmark. Available at http://odysseeindicators.org/publications/PDF/denmark_nr.pdf (Accessed March 20, 2013).

Department of Energy (DOE). 2013. “Compliance and Enforcement Basics.” Building Energy Codes Program, U.S. Department of Energy. Available at http://www.energycodes.gov/compliance/basics (Accessed December 5, 2013).

Energy Efficiency \& Renewable Energy (EERE). 2013. 90\% Compliance Pilot Studies, Final Report. Available at

http://www1.eere.energy.gov/buildings/pdfs/compliance_pilot_studies_final_report.pdf (Accessed December 18, 2013).

Epstein, G., Patel, Y., McCowan, B., D’Antonio, M., and Haselhorst, S. 2005. Application of Commercial Sector Energy Code Compliance Documents for Assessing Baseline Practice: Assessing Whether Compliance Documents Can Be Used for Developing Lighting Baseline 
Data. Paper presented at the International Energy Program Evaluation Conference, New York, N.Y., August 17-19.

Evans, M., Shui, B., Halverson, M., and Delgado, A. 2010. Enforcing Building Energy Codes in China: Progress and Comparative Lessons. Pacific Northwest National Laboratory; Richland, WA.

Evans, M and Yu, S. 2013. Energy Efficiency Improvement in Multi-Family Residential Buildings: Lessons Learned from the European Experience. PNNL-22302, Pacific Northwest National Laboratory, Richland, WA.

Global Buildings Performance Network (GBPN). 2013. Policy Comparative Tool: Denmark. Available at http://www.gbpn.org/databases-tools/bc-detail-pages/denmark\#Code History and Future Targets (Accessed December 5, 2013).

U.S. Government Printing Office (GPO). 2013. DOE Activities and Methodology for Assessing Compliance with Building Energy Codes. Federal Register. Vol. 78, No. 151, Tuesday, August 6, 2013, Notices. Available at http://www.gpo.gov/fdsys/pkg/FR-2013-08-06/pdf/201318952.pdf (Accessed December 18, 2013).

Harper, B., Badger, L., Chiodo, J., Reed, G., and Wirtshafter, R. 2012. Improved code enforcement: a powerful policy tool - lessons learned from New York State. Proceedings of the 2012 ACEEE Summer Study on Energy Efficiency in Buildings, pp 8114-8126; Pacific Grove, CA.

International Energy Agency (IEA). 2013. Modernizing Building Energy Codes to Secure our Global Energy Future. Available at http://www.iea.org/publications/freepublications/publication/PP7_Building_Codes_2013_WEB. pdf (Accessed December 10, 2013).

IEEMA. 2007. Energy Conservation Building Code - Powering Energy Conservation. Available at

http://www.energymanagertraining.com/Journal/05112007/EnergyConservationBuildingCode.pd f (Accessed November 8, 2013). 
Karlsson-Hjorth, H. 2013. Swedish Compliance System. Presentation at the Getting Building Codes Right: Implementation and Enforcement (Training Webinar). Available at: https://cleanenergysolutions.org/training/getting-building-codes-right-2014 .

Khawaja, M., Lee, A., and Levy, M. 2007. Statewide Codes and Standards Market Adoption and Noncompliance Rates. Prepared for Southern California Edison. Available at:

http://www.calmac.org/publications/Codes_and_Standards_Final_Report.pdf. Quantec, LLC; Portland, OR.

Kumar, S., Kapoor, R., Rawal, R., Seth, S., and Walia, A. 2010. Developing an Energy Conservation Building Code Implementation Strategy in India. Proceedings of the 2010 ACEEE Summer Study on Energy Efficiency in Buildings, pp 8209-8224; Pacific Grove, CA.

Manu, S., Wong, J., Rawal, R., Thomas, P., Kumar, S., and Deshmukh, A. 2011. An initial parametric evaluation of the impact of the energy conservation building code of India on commercial building sector. Proceedings of Building Simulation 2011: 12 ${ }^{\text {th }}$ Conference of International Building Performance Simulation Association; Sydney, Australia.

Misuriello, H., Penney, S., Eldridge, M., and Foster, B. 2010. Lessons Learned from Building Energy Code Compliance and Enforcement Evaluation Studies. Proceedings of the 2010 ACEEE Summer Study on Energy Efficiency in Buildings, pp 8245-8255; Pacific Grove, CA

McCormick, K. and Neij, L. 2009. Experience of Policy Instruments for Energy Efficiency in Buildings in the Nordic Countries. IIIEE and Lund University, Lund, Sweden.

MOHURD. 2011. Report on 2010 National Special Inspection for Building Energy Efficiency (in Chinese). Ministry of Housing and Urban-Rural Development; Beijing, China. Available at http://www.mohurd.gov.cn/zcfg/jsbwj_0/jsbwjjskj/ 201104/t20110421_203196.html (Accessed December 10, 2013).

Nordeen, G. 2013. The Washington State Experience Residential Energy Code Compliance. Washington State University Extension Energy Program. Available at http://www.energycodes.gov/sites/default/files/documents/codeMeeting/Gary\%20Nordeen.pdf (Accessed December 2, 2013). 
Pacific Northwest National Laboratory (PNNL). 2010. Measuring State Energy Code Compliance. Pacific Northwest National Laboratory; Richland, WA. Available at http://www.energycodes.gov/sites/default/files/documents/MeasuringStateCompliance.pdf .

Price, L., Levine, M., Zhou, N., Fridley, D., Aden, A.; Lu, H., McNeil, M., Zheng, N., Qina, Y., and Yowarganab, P. 2011. "Assessment of China's Energy-Saving and Emission-Reduction Accomplishments and Opportunities During the 11th Five Year Plan." Energy Policy 39 (4): 2165-2178.

Rawal, R., Vaidya, V., Ghatti, V., Ward, A., Seth, S., Jain, A., and Parthasarathy, T. 2012. Energy Code Enforcement for Beginners: A Tiered Approach to Energy Code in India. Proceedings of the 2012 ACEEE Summer Study on Energy Efficiency in Buildings, pp 43134324; Pacific Grove, CA.

Danish Building Research Institute (SBi). 2008. Energy calculation. Available at http://www.sbi.dk/en/research/energy_and_environment/energy-calculation/ (Accessed December 5, 2013).

Shnapp, S. and Laustsen, J. 2013. Mitigation Potential from India's Buildings. Global Buildings Performance Network; Paris, France.

Swedish Energy Agency (SEA). 2012. Energy Efficiency Policies and Measures in Sweden. ODYSSEE-MURE; Eskilstuna, Sweden.

SEA. 2013. Energy Efficiency in the Built Environment-New Research and Innovation Program. SEA. Stockholm. Available at http://energimyndigheten.se/en/About-us/Press/News/Energy-efficiency-in-the-built-environment--new-research-and-innovation-programinitiated/ (Accessed March 20, 2013).

Shakti Foundation. 2013. The Third Party Assessor Model for ECBC Compliance and Enforcement. Available at http://www.carbse.org/wpcontent/uploads/2013/08/TPA_brochure.pdf (Accessed December 20, 2013).

Shui, B. 2012. Third Parties in the Implementation of Building Energy Codes in China. Institute for Market Transformation, American Council for Energy-Efficient Economy; Washington, D.C. 
Shui, B. and Nadel, S. 2012. How does China achieve a 95\% compliance rate for building energy codes?: A discussion about China's inspection system and compliance rates. Proceedings of the 2012 ACEEE Summer Study on Energy Efficiency in Buildings, pp 814-826; Pacific Grove, CA.

Stellberg, S. 2013. Assessment of Energy Efficiency Achievable from Improved Compliance with U.S. Building Energy Codes: 2013 - 2030. Institute for Market Transformation; Washington, D.C.

Tulsyan, A., Dhaka, S., Mathur, J., and Yadv, J.V. 2013. Potential of energy savings through implementation of Energy Conservation Building Code in Jaipur city, India. Energy and Buildings, 58, 123-130.

UNDP. Energy Efficiency Improvements in Commercial Buildings. United Nations Development Programme India: Global Environment Facility Project Document. Available at http://www.undp.org/content/dam/india/docs/energy_efficiency_improvements_in_commercial buildings_project_document.pdf (Accessed May 5, 2012).

Williams, C. and Levine, M. 2012. Gauging Improvements in Urban Building Energy Policy in India. Proceedings of the 2012 ACEEE Summer Study on Energy Efficiency in Buildings, pp 4414-4425; Pacific Grove, CA.

Xenergy. 2003. Final Report: Phase 1 Evaluation of the Efficiency Vermont Residential New Construction Program. Prepared for the Vermont Department of Public Service. Available at: http://www.cee1.org/eval/db_pdf/420.pdf. XENERGY Inc.; Burlington, MA.

Yu, S., Makela E., Evans, M., \& Mathur, J. 2012. Recommendations on Implementing the Energy Conservation Building Code in Rajasthan, India. PNNL-21054, Pacific Northwest National Laboratory, Richland, WA.

Yu, S. and Evans, M. 2013. Post-Occupancy Performance: Lessons Learned from Global Experience, PNNL-22304. Pacific Northwest National Laboratory; Richland, WA.

Yu, S., Evans, M., Kumar, P., Van Wie, L., and Bhatt, V. 2013. Using Third-Party Inspectors in Building Energy Codes Enforcement in India (PNNL-22155). Pacific Northwest National Laboratory; Richland, WA. 
Yu, S., Eom, J., Evans, M., and Clarke, L. 2014. A long-term, integrated impact assessment of alternative building energy code scenarios in China. Energy Policy, available online, doi:10.1016/j.enpol.2013.11.009. 


\section{Appendix A Code Compliance in Denmark}

Denmark was among the first countries to adopt building energy codes in 1961 and has for years had fairly strict energy requirements in its building regulations (GBPN, 2013). Its current methodology for assessing code compliance was redefined when implementing codes based on the EU Energy Performance Building Directive (EPBD) in 2006. Since then, Denmark has significantly tightened its energy requirements and developed new inspection schemes, effectively modifying the way it calculates code compliance rates (SBi, 2008). The stricter requirements are also a product of Denmark's national target, which calls for using $75 \%$ less energy in buildings by 2020 relevant to 2008 (GBPN, 2013).

Denmark's current building code, which includes energy regulations, is the Danish Building Regulation 2010 (BR10). What makes the changes introduced since 2006 by the Danish particularly distinctive and ambitious is the incorporation of an energy performance target for new buildings as part of the mandatory code. BR10 is a performance-based code that requires a mandatory energy frame calculation in order to establish maximum energy demand for nonresidential buildings $\left(71.3+1650 / \mathrm{A} \mathrm{kWh} / \mathrm{m}^{2} / \mathrm{pa}\right)(\mathrm{GBPN}, 2013) .{ }^{12}$ The code covers all thermal envelope requirements and energy-using efficiency standards in the calculation, including, heating, cooling, ventilation, hot water, lighting (only non-residential), heat recovery and conversion and distribution losses. The energy performance target applies to all new types of buildings heated to at least $15^{\circ} \mathrm{C}$. At the time of applying for a new building permit, the developer must document that a new building complies with the energy target (SBi, 2008). In addition, Denmark introduced a new energy labeling scheme that requires that all new buildings obtain an energy label before the owner or developer acquires a use permit.

To facilitate compliance with the new requirements, the Danish Building Research Institute (SBi) developed the compliance software, SBi Direction 213 (Sbi, 2008). The calculation program helps architects and energy consultants predict (simulate) energy consumption in the design phase. However, the software and accompanying manual also include guidelines for demonstrating that a building meets the energy requirements set out by the building code and is thus used for documenting that a building complies with the new requirements. In particular, the latest code and supporting policy incorporates many progressive aspects including, mandatory

\footnotetext{
${ }^{12} \mathrm{BR} 10$ also has energy mandates for residential buildings.
} 
computer modeling, air-tightness testing for all buildings, bioclimatic design considerations, renewable energy included in the calculation, well established boiler and HVAC testing systems and voluntary low energy classes (GBPN, 2013).

\section{References}

Global Buildings Performance Network (GBPN). 2013. Policy Comparative Tool: Denmark. Available at http://www.gbpn.org/databases-tools/bc-detail-pages/denmark\#Code History and Future Targets (Accessed December 5, 2013).

Danish Building Research Institute (SBi). 2008. Energy calculation. Available at http://www.sbi.dk/en/research/energy_and_environment/energy-calculation/ (Accessed

December 5, 2013). 


\section{Appendix B Sample Checklists for ASHRAE Standard 90.1}

The U.S. Building Energy Codes Program uses the compliance checklists to support energy code compliance checks and evaluations and to validate compliance through enforcement processes. Separate checklists are included for each climate zone and each building type (i.e. commercial and residential buildings). The checklists can be customized by state and local jurisdictions to adapt to the state's amendments to the model code. The checklists are divided into stages corresponding to traditional building inspection stages, including plan review, footing/foundation inspection, framing/rough-in inspection, plumbing rough-in inspection, mechanical rough-in inspection, mechanical rough-in inspection, rough-in electrical inspection, insulation inspection, and final inspection.

Appendix B lists several sample checklists for AHSRAE Standard 90.1-2007. The full checklists used by the U.S. Building Energy Codes Program are available at https://www.energycodes.gov/compliance/evaluation/checklists. 
Bullding ID:

Date:

Bullding Contact (optional): Name:

Bullding Name:

state:

County:

Cllmate Zone Name of Evaluator(8):

Phone:

Jurlsdiction:
Compllance Approach (check all that apply): $\square$ Prescripttve Compllance software (if used):

$\square$ onfice

$\square$ RetallMercantlle

Bullding Ownership: $\square$ state-owned

Foundation Type: $\square$ Below-Grade

Project Type: $\quad \square$ New Bullding

$\square$ Siab $\square$ Trade-OtT $\square$ Pertor
Above-Code Program:

$\square$ Warehouse/Storage $\quad \square$ Education/School $\square$ Lodging/Hotel/Motel $\square$ Restaurant/Dining/Fast Food

$\square$ High-Rise Residentla

$\square$ Healthcar

$\square$ Public Assembly/Rellglous $\square$ Other

$\square$ Local Govemment-owned $\square$ National Account $\square$ Speculative

$\square$ Private $\square$ other

$\square$ Floor Over Unconditioned Space

$\square$ Existing Bullding Addition $\square$ Existing Bulding Renovation Valuation (If Renovation):5

\begin{tabular}{|c|c|c|c|}
\hline $\begin{array}{l}\text { 90.1-2007 } \\
\text { Section \# }\end{array}$ & Plan Revlew & Complles? & Comments/Assumptions \\
\hline $\begin{array}{l}4.2 .2 \\
{[P R 1]^{1}}\end{array}$ & $\begin{array}{l}\text { Plans and/or speciflcations provide all information with which complance can be determined } \\
\text { for the bulding envelope and delineate and document where exceptions to the standard are } \\
\text { claimed. Performance compllance approach submitted for bullings with vertical fenestratlon } \\
\text { area }>40 \% \text { or skylight area }>5 \% \text {. }\end{array}$ & $\begin{array}{l}\square \text { Complles } \\
\square \text { Does Not Comply } \\
\square \text { Not Ooservable } \\
\square \text { Not Applicable }\end{array}$ & \\
\hline $\begin{array}{l}4.2 .2,6.4 .2 \\
{[P R 2]^{1}}\end{array}$ & $\begin{array}{l}\text { Plans, specifications, andior caiculations provide all information with which compllance can } \\
\text { be determined for the mechanical systems and equipment and dellineate and document } \\
\text { where exceptions to the standard are claimed. }\end{array}$ & $\begin{array}{l}\square \text { Complles } \\
\square \text { Does Not Comply } \\
\square \text { Not Observable } \\
\square \text { Not Applicable } \\
\end{array}$ & \\
\hline $\begin{array}{l}4.2 .2,7.4 .1 \\
{[P R 3]^{1}}\end{array}$ & $\begin{array}{l}\text { Plans, specifications, andior calculations provide all information with which compllance can } \\
\text { be determined for the service water heating systems and equipment and dellneate and } \\
\text { document where exceptions to the standard are claimed. }\end{array}$ & $\begin{array}{l}\text { Complles } \\
\square \text { Does Not Comply: } \\
\square \text { Not Ooservable } \\
\square \text { Not Applicable }\end{array}$ & \\
\hline $\begin{array}{l}4.2 .2 \\
{[P R A]^{\prime}}\end{array}$ & $\begin{array}{l}\text { Plans, specifications, andior caiculations provide all information with which compliance can } \\
\text { be determined for the lighting and electrical systems and equipment and dellineate and } \\
\text { document where exceptions to the standard are claimed. Information provided should include } \\
\text { Interior and exterior lighting power calculations, wattage of bulos and ballasts, transformers } \\
\text { and control devices. }\end{array}$ & $\begin{array}{l}\square \text { Complles } \\
\square \text { Does Not Comply? } \\
\square \text { Not Observable } \\
\square \text { Not Applicable }\end{array}$ & \\
\hline $\begin{array}{l}6.7 .2 .4 \\
{[P R 5]^{1}}\end{array}$ & $\begin{array}{l}\text { Detalled Instructions for HVAC systems commissioning included on the plans or } \\
\text { ispeciflcations for }>-50,000 \mathrm{tt}^{2} \text {. }\end{array}$ & $\begin{array}{l}\square \text { Complles } \\
\square \text { Does Not Comply: } \\
\square \text { Not Ooservable } \\
\square \text { Not Applicable }\end{array}$ & \\
\hline $\begin{array}{l}\text { 8.4.1.1, } \\
\text { 8.4.1.2 } \\
\text { [PR. } 6]^{2}\end{array}$ & $\begin{array}{l}\text { Feeder connectors slzed in accordance with approved plans and branch circults sized for } \\
\text { maximum drop of } 3 \% \text {. }\end{array}$ & $\begin{array}{l}\square \text { Complles } \\
\square \text { Does Not Comply } \\
\square \text { Not Ooservable } \\
\square \text { Not Applicable }\end{array}$ & \\
\hline
\end{tabular}

Additional Comments/Assumptions:

\begin{tabular}{|l|l|l|l|l|l|}
\hline 1 & High Impact (Tler 1) & 2 & Medlum Impact (Tler 2) & 3 & Low Impact (Tler 3) \\
\hline
\end{tabular}


General building information only required if different than above

Date:

Name of Evaluator(s):

Building Contact (optional): Name:

Building Name:

Address:

Phone:

Compliance Approach (check all that apply): $\square$ Prescriptive

Compliance Software (if used):

Building ID:

\begin{tabular}{|c|c|c|c|c|c|}
\hline $\begin{array}{l}90.1-2007 \\
\text { Section \# }\end{array}$ & Footing / Foundation Inspection & $\begin{array}{l}\text { Plans Verified } \\
\text { Value }\end{array}$ & $\begin{array}{l}\text { Field Verified } \\
\text { Value }\end{array}$ & Complies? & Comments/Assumptions \\
\hline $\begin{array}{l}5.5 .3 .3 \\
{[\mathrm{FO} 1]^{1}}\end{array}$ & Below-grade wall insulation R-value. & R- & $\mathrm{R}-$ & $\begin{array}{l}\square \text { Complies } \\
\square \text { Does Not Comply } \\
\square \text { Not Observable } \\
\square \text { Not Applicable }\end{array}$ & \\
\hline $\begin{array}{l}5.8 .12 \\
{[\mathrm{FO} 2]^{1}}\end{array}$ & $\begin{array}{l}\text { Below-grade wall insulation installed per } \\
\text { manufacturer's instructions. }\end{array}$ & & $\begin{array}{l}\text { If complies: } \\
\square \text { Good } \\
\square \text { Fair } \\
\square \text { Poor }\end{array}$ & $\begin{array}{l}\square \text { Complies } \\
\square \text { Does Not Comply } \\
\square \text { Not Observable } \\
\square \text { Not Applicable }\end{array}$ & \\
\hline $\begin{array}{l}5.5 .3 .5 \\
{[\mathrm{FO} 3]^{1}}\end{array}$ & Slab edge insulation R-value. & $\begin{array}{l}\text { R- } \\
\square \text { Unheated } \\
\square \text { Heated }\end{array}$ & $\begin{array}{l}\square \text { - } \\
\square \text { Unheated } \\
\square \text { Heated }\end{array}$ & $\begin{array}{l}\square \text { Complies } \\
\square \text { Does Not Comply } \\
\square \text { Not Observable } \\
\square \text { Not Applicable }\end{array}$ & \\
\hline $\begin{array}{l}5.8 .12 \\
{[\mathrm{FO} 4]^{1}}\end{array}$ & $\begin{array}{l}\text { Slab edge insulation installed per manufacturer's } \\
\text { instructions. }\end{array}$ & & $\begin{array}{l}\text { If compllez: } \\
\square \text { Good } \\
\square \text { Fair } \\
\square \text { Poor }\end{array}$ & $\begin{array}{l}\square \text { Complies } \\
\square \text { Does Not Comply } \\
\square \text { Not Observable } \\
\square \text { Not Applicable }\end{array}$ & \\
\hline $\begin{array}{l}5.5 .3 .5 \\
{[\mathrm{FO} 5]^{1}}\end{array}$ & Slab edge insulation depth/length. & ${ }^{\mathrm{ft}}$ & ${ }^{\mathrm{ft}}$ & $\begin{array}{l}\square \text { Complies } \\
\square \text { Does Not Comply } \\
\square \text { Not Observable } \\
\square \text { Not Applicable }\end{array}$ & \\
\hline $\begin{array}{l}5.8 .1 .7 \\
{\left[\mathrm{FO}^{1}\right.}\end{array}$ & $\begin{array}{l}\text { Exterior insulation protected against damage, } \\
\text { sunlight, moisture, wind, landscaping and equipment } \\
\text { maintenance activities. }\end{array}$ & & & $\begin{array}{l}\square \text { Complies } \\
\square \text { Does Not Comply } \\
\square \text { Not Observable } \\
\square \text { Not Applicable }\end{array}$ & \\
\hline $\begin{array}{l}5.8 .1 .7 .3 \\
{[\mathrm{FO}]^{1}}\end{array}$ & $\begin{array}{l}\text { Insulation in contact with the ground has }<=0.3 \% \\
\text { water absorption rate per ASTM C272. }\end{array}$ & & & $\begin{array}{l}\square \text { Complies } \\
\square \text { Does Not Comply } \\
\square \text { Not Observable } \\
\square \text { Not Applicable }\end{array}$ & \\
\hline $\begin{array}{l}6.3 .2,6.4 .4 .1 \\
6.4 .4 .2 \\
{[\mathrm{FO} 8]^{1}}\end{array}$ & $\begin{array}{l}\text { Piping. ducts and plenum are insulated and sealed } \\
\text { when installed in or under a slab. }\end{array}$ & R- & & $\begin{array}{l}\square \text { Complies } \\
\square \text { Does Not Comply } \\
\square \text { Not Observable } \\
\square \text { Not Applicable }\end{array}$ & \\
\hline $\begin{array}{l}6.4 .3 .8 \\
{[\mathrm{FOO}]^{3}}\end{array}$ & $\begin{array}{l}\text { Freeze protection and snowlice melting system } \\
\text { sensors for future connection to controls. }\end{array}$ & & & $\begin{array}{l}\square \text { Complies } \\
\square \text { Does Not Comply } \\
\square \text { Not Observable } \\
\square \text { Not Applicable }\end{array}$ & \\
\hline
\end{tabular}

Additional Comments/Assumptions:

\begin{tabular}{|l|l|l|l|l|l|}
\hline 1 & High Impact (Tier 1) & 2 & Medium Impact (Tier 2) & 3 & Low Impact (Tier 3) \\
\hline
\end{tabular}


Date:

Building Contact (optional): Name:

Building Name:

Compliance Approach (check all that apply): $\square$ Prescriptive

Compliance Software (if used):
Name of Evaluator(s)

Address:__ Phone:__ Email:

\section{$\square$ Trade-Off $\square$ Performance}

Above-Code Program:

\begin{tabular}{|c|c|c|c|c|c|}
\hline $\begin{array}{l}90.1-2007 \\
\text { Section \# }\end{array}$ & Insulation Inspection & $\begin{array}{l}\text { Plans Verified } \\
\text { Value }\end{array}$ & $\begin{array}{l}\text { Field Verified } \\
\text { Value }\end{array}$ & Complies? & Comments/Assumptions \\
\hline $\begin{array}{l}5.4 .3 .1 \\
{[\mathrm{IN} 1]^{1}}\end{array}$ & $\begin{array}{l}\text { All sources of air leakage in the building thermal } \\
\text { envelope are sealed, caulked, gasketed or weather } \\
\text { stripped to minimize air leakage. }\end{array}$ & & & $\begin{array}{l}\square \text { Complies } \\
\square \text { Does Not Comply } \\
\square \text { Not Observable } \\
\square \text { Not Applicable }\end{array}$ & \\
\hline $\begin{array}{l}5.5 .3 .1 \\
{\left[{ }^{1 N} 2\right]^{1}}\end{array}$ & $\begin{array}{l}\text { Roof R-value. For some roof systems, verification } \\
\text { may need to occur during Framing Inspection. }\end{array}$ & $\begin{array}{l}\text { R- } \\
\square \text { Above deck } \\
\square \text { Metal } \\
\square \text { Attic }\end{array}$ & $\begin{array}{l}\text { R- } \\
\square \text { Above deck } \\
\square \text { Metal } \\
\square \text { Attic }\end{array}$ & $\begin{array}{l}\square \text { Complies } \\
\square \text { Does Not Comply } \\
\square \text { Not Observable } \\
\square \text { Not Applicable }\end{array}$ & \\
\hline $\begin{array}{l}5.8 .12 \\
5.8 .1 .3 \\
{[\mathrm{IN} 3]^{1}}\end{array}$ & $\begin{array}{l}\text { Roof insulation installed per manufacturer's } \\
\text { instructions. Blown or poured loose-fill insulation is } \\
\text { installed only where the roof slope is }<=3 \text { in } 12 \text {. }\end{array}$ & & $\begin{array}{l}\text { If comples: } \\
\square \text { Good } \\
\square \text { Fair } \\
\square \text { Poor }\end{array}$ & $\begin{array}{l}\square \text { Complies } \\
\square \text { Does Not Comply } \\
\square \text { Not Observable } \\
\square \text { Not Applicable }\end{array}$ & \\
\hline $\begin{array}{l}5.5 .3 .1 \\
{[\mathrm{IN} 4]^{3}}\end{array}$ & $\begin{array}{l}\text { Skylight curbs insulated to the level of roofs with } \\
\text { insulation above deck or R-5. }\end{array}$ & R- & R- & \begin{tabular}{|l|} 
Complies \\
$\square$ Does Not Comply \\
$\square$ Not Observable \\
$\square$ Not Applicable
\end{tabular} & \\
\hline $\begin{array}{l}5.5 .3 .1 .1 \\
{[\mathrm{IN} 5]^{3}}\end{array}$ & $\begin{array}{l}\text { High-albedo roofs meet solar reflectance of } 0.70 \text { and } \\
\text { thermal emittance of } 0.75 \text { or SRI of } 82 \text {. }\end{array}$ & SR: & SR: & $\begin{array}{l}\square \text { Complies } \\
\square \text { Does Not Comply } \\
\square \text { Not Observable } \\
\square \text { Not Applicable }\end{array}$ & \\
\hline $\begin{array}{l}5.5 .3 .2 \\
{\left[\mathrm{IN}^{1}\right]^{1}}\end{array}$ & Above-grade wall insulation R-value. & $\begin{array}{l}\text { R- } \\
\square \text { Mass } \\
\square \text { Metal } \\
\square \text { Steel } \\
\square \text { Wood }\end{array}$ & $\begin{array}{l}\text { R- } \\
\square \text { Mass } \\
\square \text { Metal } \\
\square \text { Steel } \\
\square \text { Wood }\end{array}$ & $\begin{array}{l}\square \text { Complies } \\
\square \text { Does Not Comply } \\
\square \text { Not Observable } \\
\square \text { Not Applicable }\end{array}$ & \\
\hline $\begin{array}{l}5.8 .1 .2 \\
{\left[{ }^{1 N} 7\right]^{1}}\end{array}$ & $\begin{array}{l}\text { Above-grade wall insulation installed per } \\
\text { manufacturer's instructions. }\end{array}$ & & $\begin{array}{l}\text { If comolles: } \\
\square \text { Good } \\
\square \text { Fair } \\
\square \text { Poor }\end{array}$ & $\begin{array}{l}\square \text { Complies } \\
\square \text { Does Not Comply } \\
\square \text { Not Observable } \\
\square \text { Not Applicable }\end{array}$ & \\
\hline $\begin{array}{l}5.5 .3 .4 \\
\text { [INB] }^{1}\end{array}$ & Floor insulation R-value. & $\begin{array}{l}\text { R- } \\
\square \text { Mass } \\
\square \text { Steel } \\
\square \text { Wood }\end{array}$ & $\begin{array}{l}\text { R- } \\
\square \text { Mass } \\
\square \text { Steel } \\
\square \text { Wood }\end{array}$ & $\begin{array}{l}\text { Complies } \\
\square \text { Does Not Comply } \\
\square \text { Not Observable } \\
\square \text { Not Applicable }\end{array}$ & \\
\hline $\begin{array}{l}5.8 .1 .2 \\
\text { [INE] }^{1}\end{array}$ & $\begin{array}{l}\text { Floor insulation installed per manufacturer's } \\
\text { instructions. }\end{array}$ & & $\begin{array}{l}\text { If complies: } \\
\square \text { Good } \\
\square \text { Fair } \\
\square \text { Poor }\end{array}$ & $\begin{array}{l}\square \text { Complies } \\
\square \text { Does Not Comply } \\
\square \text { Not Observable } \\
\square \text { Not Applicable }\end{array}$ & \\
\hline $\begin{array}{l}5.8 .1 .1 \\
{[\mathrm{IN} 10]^{2}}\end{array}$ & $\begin{array}{l}\text { Building envelope insulation is labeled with R-value or } \\
\text { insulation certificate providing R-value and other } \\
\text { relevant data. }\end{array}$ & & & $\begin{array}{l}\square \text { Complies } \\
\square \text { Does Not Comply } \\
\square \text { Not Observable } \\
\square \text { Not Applicable }\end{array}$ & \\
\hline $\begin{array}{l}5.8 .1 .4 \\
{[\text { IN } 11]^{2}}\end{array}$ & $\begin{array}{l}\text { Eaves are baffled to deflect air to above the } \\
\text { insulation. }\end{array}$ & & & $\begin{array}{l}\square \text { Complies } \\
\square \text { Does Not Comply } \\
\square \text { Not Observable } \\
\square \text { Not Applicable }\end{array}$ & \\
\hline $\begin{array}{l}5.8 .1 .5 \\
{[\mathrm{IN} 12]^{2}}\end{array}$ & $\begin{array}{l}\text { Insulation is installed in substantial contact with the } \\
\text { inside surface separating conditioned space from } \\
\text { unconditional space. }\end{array}$ & & $\begin{array}{l}\text { If comoles: } \\
\square \text { Good } \\
\square \text { Fair } \\
\square \text { Poor }\end{array}$ & $\begin{array}{l}\square \text { Complies } \\
\square \text { Does Not Comply } \\
\square \text { Not Observable } \\
\square \text { Not Applicable }\end{array}$ & \\
\hline $\begin{array}{l}5.8 .1 .6 \\
{[\mathrm{IN} 13]^{2}}\end{array}$ & $\begin{array}{l}\text { Recessed equipment installed in building envelope } \\
\text { assemblies does not compress the adjacent } \\
\text { insulation. }\end{array}$ & & & $\begin{array}{l}\square \text { Complies } \\
\square \text { Does Not Comply } \\
\square \text { Not Observable } \\
\square \text { Not Applicable }\end{array}$ & \\
\hline
\end{tabular}

\begin{tabular}{|l|l}
\hline 1 & High Impact (Tier 1) \\
\hline
\end{tabular}

3 Low Impact (Tier 3)

Page 9 of 12

\begin{tabular}{|l|l}
2 & Medium Impact (Tier 2)
\end{tabular} 
Date:

Building Contact (optional): Name:

Building Name:

Compliance Software (if used):
Name of Evaluator(s):

Building ID:

Email:

Conditioned Floor Area:
Phone:

$\square$ Trade-Off $\square$ Performance Above-Code Program:

\begin{tabular}{|c|c|c|c|}
\hline $\begin{array}{l}90.1-2007 \\
\text { Section \# }\end{array}$ & Final Inspection & Complies? & Comments/Assumptions \\
\hline $\begin{array}{l}5.4 .3 .3 \\
{[\mathrm{FI} I]^{1}}\end{array}$ & Weatherseals installed on all loading dock cargo doors in Climate Zones 4-8. & $\begin{array}{l}\square \text { Complies } \\
\square \text { Does Not Comply } \\
\square \text { Not Observable } \\
\square \text { Not Applicable }\end{array}$ & \\
\hline $\begin{array}{l}6.4 .3 .1 .1 \\
{[\mathrm{FI} / 2]^{2}}\end{array}$ & Heating and cooling to each zone is controlled by a thermostat control. & $\begin{array}{l}\square \text { Complies } \\
\square \text { Does Not Comply } \\
\square \text { Not Observable } \\
\square \text { Not Applicable }\end{array}$ & \\
\hline $\begin{array}{l}6.4 .3 .1 .2 \\
6.4 .3 .2 \\
6.4 .3 .3 \\
6.4 .3 .3 .1 \\
6.4 .3 .3 .2 \\
{[\mathrm{~F} \mid 3]^{2}}\end{array}$ & $\begin{array}{l}\text { Temperature controls have the following features: dead band controls, setpoint overlap } \\
\text { restrictions, off-hour controls, automatic shutdown, setback controls. }\end{array}$ & $\begin{array}{l}\square \text { Complies } \\
\square \text { Does Not Comply } \\
\square \text { Not Observable } \\
\square \text { Not Applicable }\end{array}$ & \\
\hline $\begin{array}{l}6.4 .3 .3 .3 \\
{[\mathrm{~F} / 4]^{2}}\end{array}$ & Systems with air capacity $>10,000 \mathrm{~cm}$ include optimum start controls. & $\begin{array}{l}\square \text { Complies } \\
\square \text { Does Not Comply } \\
\square \text { Not Observable } \\
\square \text { Not Applicable }\end{array}$ & \\
\hline $\begin{array}{l}6.4 .3 .5 \\
{[\mathrm{~F} 15]^{3}}\end{array}$ & $\begin{array}{l}\text { Heat pump controls prevent supplemental electric resistance heat from coming on when not } \\
\text { needed. }\end{array}$ & $\begin{array}{l}\square \text { Complies } \\
\square \text { Does Not Comply } \\
\square \text { Not Observable } \\
\square \text { Not Applicable }\end{array}$ & \\
\hline $\begin{array}{l}6.4 .3 .7 \\
{[\mathrm{~F} \mid 6]^{3}}\end{array}$ & $\begin{array}{l}\text { When humidification and dehumidification is provided to a zone simultaneous operation is not } \\
\text { possible. }\end{array}$ & \begin{tabular}{|l|} 
Complies \\
$\square$ Does Not Comply \\
$\square$ Not Observable \\
$\square$ Not Applicable
\end{tabular} & \\
\hline $\begin{array}{l}6.7 .2 .1 \\
{[\mathrm{~F} 17]^{3}}\end{array}$ & Furnish HVAC "as-built" drawings submitted within 90 days of system acceptance. & $\begin{array}{l}\square \text { Complies } \\
\square \text { Does Not Comply } \\
\square \text { Not Observable } \\
\square \text { Not Applicable }\end{array}$ & \\
\hline $\begin{array}{l}6.7 .2 .2 \\
{[\mathrm{~F} 18]^{3}}\end{array}$ & Fumish O\&M manual for HVAC systems. & $\begin{array}{l}\square \text { Complies } \\
\square \text { Does Not Comply } \\
\square \text { Not Observable } \\
\square \text { Not Applicable }\end{array}$ & \\
\hline $\begin{array}{l}6.7 .2 .3 \\
{[\mathrm{~F} \mid 9]^{1}}\end{array}$ & $\begin{array}{l}\text { An air and/or hydronic system balancing report is provided for HVAC systems serving zones } \\
>5,000 \mathrm{ft}^{2} \text { of conditioned area. }\end{array}$ & \begin{tabular}{|l|} 
Complies \\
$\square$ Does Not Comply \\
$\square$ Not Observable \\
$\square$ Not Applicable
\end{tabular} & \\
\hline $\begin{array}{l}6.7 .2 .4 \\
{[\mathrm{~F} 110]^{1}}\end{array}$ & $\begin{array}{l}\text { Verify HVAC control systems have been tested to ensure proper operation, calibration and } \\
\text { adjustment of controls. }\end{array}$ & $\begin{array}{l}\text { Complies } \\
\square \text { Does Not Comply } \\
\square \text { Not Observable } \\
\square \text { Not Applicable }\end{array}$ & \\
\hline $\begin{array}{l}7.4 .4 .3 \\
{[\mathrm{~F} 111]^{3}}\end{array}$ & Public lavatory faucet water temperature not greater than $110^{\circ} \mathrm{F}$. & $\begin{array}{l}\square \text { Complies } \\
\square \text { Does Not Comply } \\
\square \text { Not Observable } \\
\square \text { Not Applicable }\end{array}$ & \\
\hline $\begin{array}{l}7.4 .4 .4 \\
{[\mathrm{~F} I 12]^{3}}\end{array}$ & $\begin{array}{l}\text { Controls are installed that limit the operation of a recirculation pump installed to maintain } \\
\text { temperature of a storage tank. }\end{array}$ & \begin{tabular}{|l|} 
Complies \\
$\square$ Does Not Comply \\
$\square$ Not Observable \\
$\square$ Not Applicable
\end{tabular} & \\
\hline $\begin{array}{l}7.4 .5 .1 \\
{[\mathrm{~F} I 13]^{3}}\end{array}$ & Pool heaters are equipped with on/off switch and no continuously burning pilot light. & $\begin{array}{l}\text { Complies } \\
\square \text { Does Not Comply } \\
\square \text { Not Observable } \\
\square \text { Not Applicable }\end{array}$ & \\
\hline
\end{tabular}




\section{Appendix C Tokyo Cap-and-Trade Program ${ }^{13}$}

\section{Background}

Energy use and $\mathrm{CO}_{2}$ emissions from the building sector in the metropolitan Tokyo area have grown rapidly in the past two decades. From 1990 to 2006, energy consumption in residential and commercial buildings increased $21 \%$ and $46 \%$, respectively, while energy use in the industrial sector declined over $40 \%$ and transportation energy use increased less than $1 \%$. In 2006 , the building sector accounted for $62 \%$ of energy consumption and $63 \%$ of $\mathrm{CO}_{2}$ emissions in Tokyo. The Tokyo Metropolitan Government (TMG) projected that the energy use and $\mathrm{CO}_{2}$ emissions from the building sector would continue to grow at least in the near term. To respond to this trend, TMG launched the Tokyo cap-and-trade program in April 2010 based on the Tokyo Metropolitan Environmental Security Ordinance (TMG, 2012a); this is the first program in the world that explicitly includes the buildings sector in emissions trading. The facilities to which the cap applies consist of large-scale industrial facilities and commercial buildings consuming more than 1,500 kiloliters of oil equivalent per year. In fact, around $80 \%$ of facilities covered by the program are commercial buildings.

The overall target of the Tokyo cap-and-trade program is to "reduce greenhouse gas emissions to $25 \%$ below the 2000 levels by 2020" (TMG, 2010). The program sets two compliance periods (2010-2014 and 2015-2019), and aims to reduce emissions by $6-8 \%{ }^{14}$ and $17 \%$, respectively, compared to 2000. Facilities can bank their surplus when their actual emissions are less than the allowances in a given compliance period, but they cannot borrow allowances from a future compliance period. The five-year compliance period provides companies some flexibility and enables them to reduce energy use and $\mathrm{CO}_{2}$ emissions steadily through planned investments.

Facilities covered by the program have mandatory emissions reduction obligations during the five-year compliance period. They are required to report and publish their annual emissions and emissions reduction plans; third-party agencies verify their annual emissions reductions. During the first year of implementation, commercial buildings reduced emissions by $11 \%$ in comparison to the base-year emissions (TMG, 2012a).

\footnotetext{
${ }^{13}$ Appendix C is adapted from the following report: Yu, S. and Evans, M. 2013. Post-Occupancy Performance: Lessons Learned from Global Experience, PNNL-22304. Pacific Northwest National Laboratory; Richland, WA.

${ }^{14}$ The program requires that compared to the base year, commercial buildings reduce emissions by $8 \%$ or more and industrial facilities reduce emissions by $6 \%$ or more during the first compliance period (2010-2014).
} 


\section{Private Sector Involvement}

The program has brought in various stakeholders, especially building tenants and top management of the real estate sector. TMG started mandatory emissions reporting and voluntary emissions reduction in 2000. This has raised awareness among stakeholders in the past decade; it has also made most stakeholders familiar with emissions reporting and reduction measures. However, when the cap-and-trade program was announced in 2007, there was strong opposition from the private sector. To motivate stakeholders, TMG built an inclusive stakeholder consultation process, involved stakeholders in the program design, addressed their concerns and reached consensus among business groups ${ }^{15}$; the strong leadership and commitment from TMG also contributed to the success of the program (Nishida and Hua, 2011). In addition, utilities in Tokyo collaborated with TMG and provided energy data from large buildings; TMG used energy use and emissions data collected since 2000 to show stakeholders the energy-saving and emissions-reduction potential, and this helped convince most stakeholders (personal communication with $\mathrm{TMG}^{16}$ ).

To reduce actual energy consumption in buildings, the program needs collaboration between building owners and tenants. Tenants have the responsibility to cooperate with owners to reduce emissions and are required to submit energy-saving plans to TMG. Before launching the program, TMG held seminars for tenants to share experiences of energy efficiency improvement and help tenants understand the benefits. In addition, the cap-and-trade program covers all large commercial buildings in Tokyo, so tenants of large buildings could not choose to exempt from the program (TMG, 2012b).

\section{Link with Building Energy Code and Compliance Mechanism}

The Tokyo cap-and-trade program is backed by the Tokyo Metropolitan Environmental Security Ordinance, which was amended in 2008 and set mandatory energy efficiency requirements for newly-built large commercial buildings. These energy-saving requirements are used as prerequisites for new buildings participating in the cap-and-trade program. For existing

\footnotetext{
${ }^{15}$ For example, through the discussion with developers, the roles and obligations of tenants in the program were strengthened. Another example is that the Tokyo Chamber of Commerce and Industry turned from opposition to active participation after realizing that the program could benefit small business.

${ }^{16}$ PNNL held a conference call with the TMG Bureau of Environment in February 2012; this discussion helped us understand the Tokyo cap-and-trade program in detail.
} 
buildings, baseline emissions are set by using actual emissions data in three consecutive years prior to the program.

The Measurement Law of Japan mandates that electricity and gas suppliers use effective measurement gauges and install energy meters to monitor building energy consumption, and large commercial buildings are also required to have sub-metering to monitor power consumption. Therefore, the actual energy use and emissions of covered facilities are monitored and measured on an annual basis based on data from metering, sub-metering and utility bills. In addition, to help facilities verify their base-year emissions and report the current year emissions, TMG has collaborated with energy suppliers to send facilities their energy use data in the previous years.

Although the compliance period is five years, TMG requires building owners to report energy consumption ${ }^{17}$ to TMG, and to report and publish emissions data as well as plans for energy efficiency improvements annually. TMG also uses third-party agencies to conduct energy audits and verify emissions reported by building owners; third-party verifiers need to register with TMG and renew their licenses every three years. If facilities do not fulfill the reporting and publication obligations, they will be penalized with fines and public notification of violations. Similarly, third-party verifiers will be penalized if their obligations are not fulfilled.

The program sets an absolute cap on emissions, and covered facilities have a mandatory obligation to keep their emissions within their allowances. TMG will do a compliance assessment after completing the five-year compliance period. If facilities fail to stay within their allowances $^{18}$, they will be penalized with fines, public notification of violations and surcharges in proportion to their emissions over the cap.

\section{Program Impacts}

The Tokyo cap-and-trade program uses both "carrots and sticks" to ensure compliance; this resulted in high compliance rate and actual emissions reduction. The Tokyo cap-and-trade program requires covered facilities to submit and publish their emissions and emissions

\footnotetext{
${ }^{17}$ Energy consumption data of covered facilities are reported to TMG; because these data are business sensitive, TMG only uses them for verification and program design improvements, and does not disclose them.

${ }^{18}$ The permitted allowances are the combination of facilities' own allowances and additional allowances they purchase.
} 
reduction plans annually. By March 2012, 1,159 out of 1,348 covered facilities submitted the report for the first year of the program (TMG, 2012a). 64\% of the 1,159 facilities have reduced emissions by $8 \%$ and more, and $26 \%$ of these facilities achieved emissions reduction of $17 \%$ or more. A total of 5,764 energy-saving measures have been taken to improve energy efficiency and reduce emissions. This resulted in deployment of energy efficiency equipment, improved energy management and behavior change of building tenants. Table 1 includes detailed information on these measures.

Table 1. Major Energy Efficiency Measures Implemented under the Tokyo Cap-and-Trade Program

\begin{tabular}{|c|c|c|}
\hline Category & $\begin{array}{l}\text { Number } \\
\text { of } \\
\text { measures } \\
\text { deployed }\end{array}$ & Examples \\
\hline $\begin{array}{l}\text { HVAC } \\
\text { systems }\end{array}$ & 1,602 & $\begin{array}{l}\text { - Upgrading air-conditioning equipment } \\
\text { - Reviewing and adjusting air conditioner operating hours } \\
\text { - Reviewing and adjusting operation schedules of fans in } \\
\text { garages } \\
\text { - Introducing adequate natural ventilation }\end{array}$ \\
\hline $\begin{array}{l}\text { Lighting } \\
\text { and power } \\
\text { systems }\end{array}$ & 1,436 & $\begin{array}{l}\text { - Using LED, high frequency, or high luminance lighting } \\
\text { - Placing control devices such as motion sensors } \\
\text { - Turning off lights when not using rooms } \\
\text { - Upgrade to high-efficiency transformers }\end{array}$ \\
\hline $\begin{array}{l}\text { Heat } \\
\text { sources }\end{array}$ & 897 & $\begin{array}{l}\text { - Upgrading chillers } \\
\text { - Automatically reset temperature controls by return water } \\
\text { temperature }\end{array}$ \\
\hline $\begin{array}{l}\text { Equipment } \\
\text { and } \\
\text { appliances }\end{array}$ & 302 & $\begin{array}{l}\text { - Upgrade to energy-saving vending machine } \\
\text { - Stopping hot water supply to washroom except winter }\end{array}$ \\
\hline $\begin{array}{l}\text { General } \\
\text { management }\end{array}$ & 275 & $\begin{array}{l}\text { - Developing energy-saving management plan (including } \\
\text { tenants) } \\
\text { - Offering energy consumption data to tenants } \\
\text { - Energy-saving education for employees } \\
\text { - Applying building energy management system }\end{array}$ \\
\hline
\end{tabular}

(Source: TMG, 2012a) 


\section{Lessons Learned}

Effective program design to ensure energy savings and emissions reduction. The program requires an absolute cap in addition to an intensity target. The program requires mandatory emissions reductions; it also uses comprehensive methods to measure and monitor compliance and sets stringent sanctions for violations.

Comprehensive mechanism to measure compliance. The five-year compliance period gives building owners some flexibility to make planned investments, but the progress towards compliance is tracked on an annual basis. The program requires mandatory reporting and publication of emissions data for all covered facilities and uses third-party agencies to verify actual emissions. This helps facilities, TMG and the public to track compliance progress and enforce energy efficiency measures in a timely manner. In addition, the program uses actual energy use to set baselines and calculate annual emissions; this helps building owners understand the real effect of improving building energy efficiency. Finally, a comprehensive compliance assessment is required at the end of the compliance period and severe sanctions will be applied for noncompliance.

Broad and effective stakeholder outreach and educational program. To gain broad support, TMG hosted a series of stakeholder consultations and addressed stakeholders' concerns in the program design. In addition, the program gained high-level political support and support from top business executives. Finally, the program is developing a business environment in which energy efficiency investment is valued by the private sector.

\section{References}

TMG (2010). Tokyo Cap-and-Trade Program: Japan's First Mandatory Emissions Trading Scheme. Bureau of the Environment, Tokyo Metropolitan Government, Tokyo, Japan.

TMG (2012a). The Tokyo Cap-and-Trade Program Results of the First Fiscal Year of Operation (Provisional Results), available at http://www.kankyo.metro.tokyo.jp/en/climate/attachement/Result\%20of\%20the\%20First\%20FY \%20of\%20the\%20Tokyo\%20CT\%20Program_final.pdf 
TMG (2012b). Tokyo Cap-and-Trade Program for Large Facilities. Bureau of the Environment, Tokyo Metropolitan Government, Tokyo, Japan.

Yuko Nishida \& Ying Hua (2011). Motivating Stakeholders to Deliver Change: Tokyo's Capand-Trade Program. Building Research \& Information, 39:5, 518-533. 